\title{
Development of a design and implementation process for the integration of hydrokinetic devices into existing infrastructure in South Africa
}

\author{
CM Niebuhr ${ }^{1 *}$, M Van Dijk' and JN Bhagwan ${ }^{2}$ \\ 'Department of Civil Engineering, University of Pretoria, Pretoria, 0001, South Africa \\ ${ }^{2}$ Water Research Commission, Private Bag X03, Gezina 0031, South Africa
}

\begin{abstract}
In South Africa there is currently no notable use of modern small-scale hydrokinetic (HK) energy systems, mainly due to formerly low-cost coal-powered electricity. This renewable energy option makes use of the kinetic energy from flowing water, rather than potential energy, which is more often used in conventional hydropower. Updated refined versions of this technology are now being investigated and manufactured due to the global drive towards reducing carbon emissions and increasing energy efficiency. These modular units allow for installation of $\mathrm{HK}$ turbines into existing water infrastructure with very little civil works. The study's objective was to develop a simplified design and implementation process for HK devices within the South African legislative and regulatory environment. Approximately 66\% of South Africa's water supply is used by the agricultural sector with more than $6500 \mathrm{~km}$ of canal systems running through many areas which could benefit from alternative energy sources. The recent electricity crisis in the country allowed for problem resolution through funding opportunities and thereby an introduction of an innovative and sustainable technology to provide renewable electricity where otherwise not feasible. A pilot HK project was implemented in an applicable section on the Boegoeberg irrigation canal in the Northern Cape Province and tested for optimum functionality and correct application. This process allowed evolution of a development process for the implementation of HK devices in existing water infrastructure.
\end{abstract}

Keywords: hydrokinetic turbine, water infrastructure, renewable energy, hydropower, small-scale

\section{INTRODUCTION}

Fossil fuels are currently the primary resource for electricity generation in South Africa (SA). However, the availability of renewable energy resources is abundant and holds the potential to assist in solving issues such as reducing greenhouse gas emissions and having larger energy security by diversifying the supply (Kusakana and Vermaak, 2013).

In 2012, Kusakana and Vermaak found approximately 6000-8 000 potential sites for traditional hydropower installation in SA. The Department of Minerals and Energy (DME) of the Government of SA revealed the country to have a considerable potential for small- and large-scale hydropower generation; however, only a handful of small hydropower developments have been undertaken in the past 30 years (DME, 2003; Koko and Kusakana, 2014). Currently about 3700 MW of installed hydropower exists in SA although there remains a great lack of knowledge on hydropower and especially hydrokinetic (HK) systems.

Prior to the case study referred to in this paper there was no existing modern HK installation in SA, although the country was previously reported to have a great potential thereof (Kusakana and Vermaak, 2013). SA is a water-scarce country resulting in highly protected water infrastructure. A challenge for implementation of HK systems lies in the ownership of the infrastructure (canals etc.) onto which such systems are installed versus the mandate of the 'owner' in having such systems installed. A general perception exists that hydropower is not fit for installations in SA due to the lack of availability of components, as well as the drawn out regulatory and

*Corresponding author, email: Chantel.niebuhr@up.ac.za Received 19 March 2018; accepted in revised form 19 June 2019 legislative procedures. It is believed that all these problems have arisen due to lack of knowledge of hydropower systems (due to scarcity of existing systems) and therefore the inability to predict any environmental/social impacts thereof.

Hydropower is also misunderstood and, in many cases, believed to consume or pollute water resources. In the case of HK systems, these can be installed in line with existing infrastructure (or designed to be incorporated with new infrastructure in that instance) and do not require the water to be diverted (as required by most conventional hydropower schemes). Furthermore, the impact of the installation of a HK system into existing infrastructure is novel in SA. The purpose of this paper is to clarify such issues and give a broader understanding of $\mathrm{HK}$ installations and the possibilities thereof in SA.

In a report on the assessment of HK turbines in open channel applications prepared by the United States Department of Energy it is stated that 'Hydrokinetic energy from flowing water in open channels has the potential to support local electricity needs with lower regulatory or capital investment rather than impounding water with more conventional means (Gunawan et al., 2017) indicating not only local but international relevance to such studies.

\section{Hydrokinetic applicability to South African canal systems}

The demand for energy in SA is increasing with a greatly fossil fuel dependent economy resulting in an unsustainable future. According to environmental statistics SA is among the top 20 countries with the highest level of carbon dioxide emissions, also being the highest emitter of greenhouse gases in Africa (MEAAI, 2011). In 2010 the DME released an Integrated 
Resource Plan (IRP) to increase renewable energy sources to 17.8 GW by 2030 (Koko and Kusakana, 2014). This allows a large opportunity for the development of renewable energy, such as biomass, wind, solar and hydropower. Details of the DME targets and evolution of the electrification goals in SA are summarized in Fig. 1.

Hydropower is a trusted technology with significant potential in SA (White, 2011). It is a form of clean renewable energy making use of the available flow or head in water without consuming or polluting the water itself. Often these hydropower systems have long lifespans and high efficiencies with low operating costs (van Vuuren et al., 2011).

Kusakana et al. (2013) investigated the possibility of HK hydropower development for rural and isolated loads in South Africa. The case studies proved that where adequate water resources are available in South Africa, HK power generation could be the best, most cost-effective supply option in relation to wind, photovoltaic and diesel generators (Kusakana and Vermaak, 2013).

A large network of canal systems exist in South Africa, the Department of Water and Sanitation (DWS) asset management database revealed a total of 47 schemes with a network of more than $6500 \mathrm{~km}$ of canals, as shown in Fig. 2. Additional to the HK potential in straight uniform sections on these canal systems, 21286 structures such as tunnels, syphons, weirs, control gates, chutes and drops exist, which could also hold unexploited HK (and conventional hydropower) potential.

HK energy extraction is a simple process; therefore the cost of energy extraction is low. Due to its modular nature the initial installation cost and deployment time is short as it does not require construction of significant infrastructure. It also allows an easily scalable energy output but limits any decrease in capital cost per $\mathrm{kW}$ output (Gaden and Bibeau, 2006). The cost of generation alone, not including the infrastructural cost itself, may be lower than traditional hydropower forms and more economical when compared to solar power (Kusakana and Vermaak, 2013).

\section{Development process}

The development process of a HK installation varies throughout the world, as each country's specific laws and regulatory processes have to be followed. As HK implementation is a new concept in SA, the development process is not yet streamlined. An outline of a suggested development process for HK integration into existing water infrastructure was compiled through results from global case studies and the pilot study completed in SA, and is depicted schematically in Fig. 3. Some of the processes are described below by means of reference to the case study.

\section{Step 1: Site-selection and pre-feasibility study}

The final HK installation site should be carefully selected, as for the case study described later in this paper. This may be a difficult task when optimal velocities are not available. HK turbines usually require a velocity of around $2-3.5 \mathrm{~m} / \mathrm{s}$ (based on available turbine operational ranges). Sites at existing narrowed sections (such as flume sections or syphon outlets) are usually more likely to have these velocities readily available; examples of these sites are shown in Table 1. When selecting sites such as these, several issues, such as high damming or interruption of the infrastructure operation (before installation) may occur; therefore, selection of a site with a higher velocity along a uniform section, where only a small fraction of the cross section is utilised for the HK installation, remains the best installation option. The site selection procedure shown in Fig. 4 may be used as a guideline to an optimal site selection process.

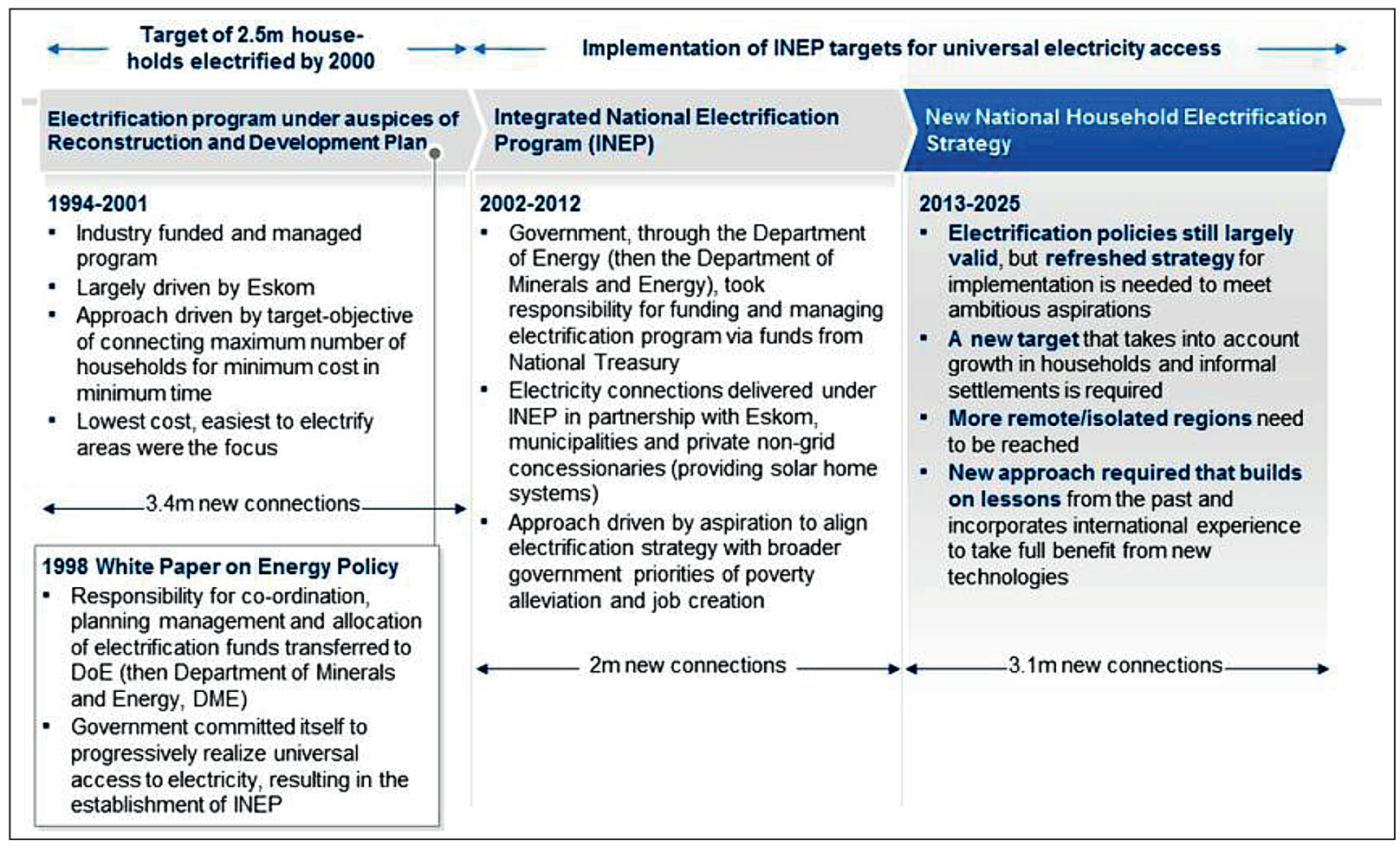

Figure 1. Evolution of electrification in South Africa (IFC, 2013) 


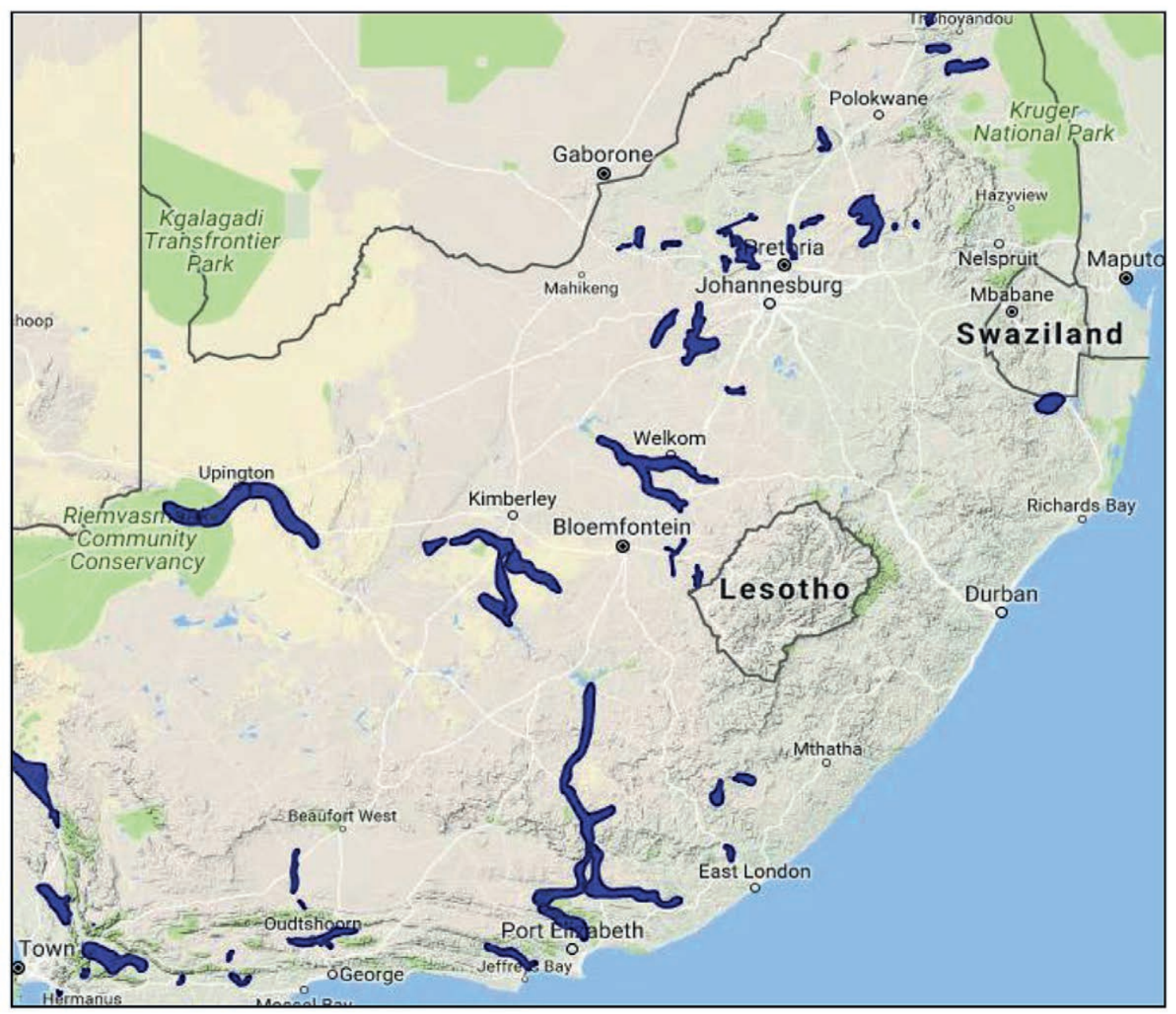

Figure 2. Canal schemes in South Africa (DWS, 2015)

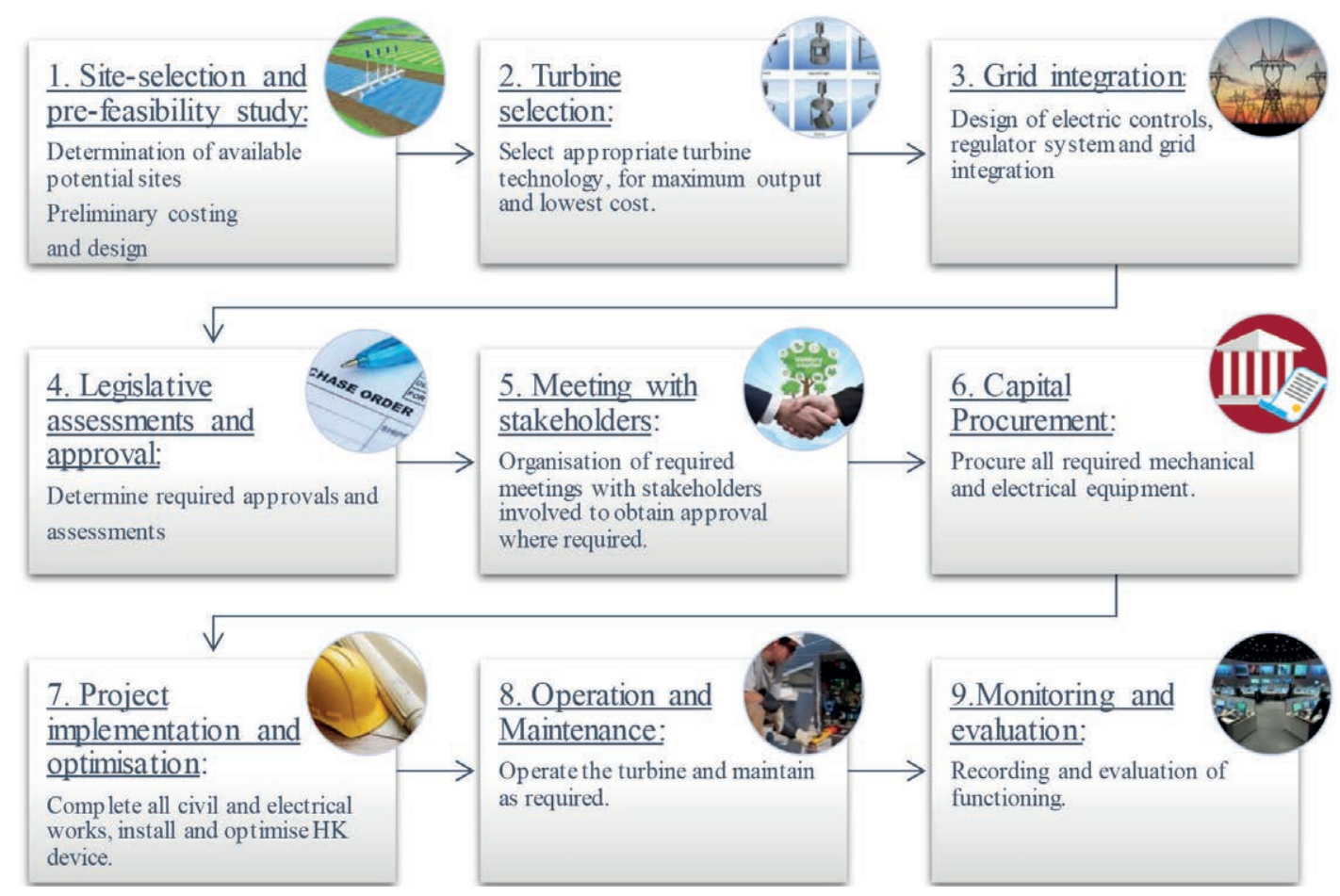

Figure 3. Canal HK system development process 
Table 1. Sections with higher velocities (DWS, 2016)

Potential site
Steep sections: Examples include
canal outlets to balancing dams,
or sections of higher gradients
Flume sections: Where a
narrowing in the canal occurs,
higher velocities may be present
Siphon/pipe exits: Where siphons are
used between canal sections the
narrowed section at the exits may
be considered as potential sites

\begin{tabular}{|c|c|c|c|c|}
\hline $\begin{array}{l}\text { HYDRAULIC } \\
\text { ANALYSIS }\end{array}$ & $\begin{array}{l}\text { LOCAL } \\
\text { ENGAGEMENT }\end{array}$ & $\begin{array}{l}\text { DESKTOP } \\
\text { STUDY }\end{array}$ & $\begin{array}{l}\text { FIHID } \\
\text { MEASUREMENTS }\end{array}$ & $\begin{array}{l}\text { FINAL SITE } \\
\text { SELECTION }\end{array}$ \\
\hline $\begin{array}{l}\text { - Historical flow } \\
\text { data } \\
\text {-Identify max } \\
\text { flow sections }\end{array}$ & $\begin{array}{l}\text { - Meeting with } \\
\text { Local } \\
\text { Municipality }\end{array}$ & $\begin{array}{l}\text { - Identify sites in } \\
\text { selected areas } \\
\text { - GS } \\
\text { measurements }\end{array}$ & $\begin{array}{l}\text { - Physical } \\
\text { measurements } \\
\text {-Site survey }\end{array}$ & $\begin{array}{l}\text { - Select most } \\
\text { appropriate site }\end{array}$ \\
\hline
\end{tabular}

Figure 4. Site selection procedure

In conjunction with site selection, a pre-feasibility study of shortlisted potential sites should be undertaken; this includes:

- Accurate velocity, flow and level measurements

- Identification of electricity use and transmission length

- Identification of connection type and point (grid integration or stand-alone scheme)

- Conceptual design

- Preliminary costing of components for economic evaluation The pre-feasibility study should be carefully completed, and all costs should be calculated and weighed against the output before final design and implementation of the HK system. The main cost considerations are shown in Fig. 5.

\section{Step 2: Turbine selection}

The HK turbine type should be carefully considered before selection. As these devices are not currently readily available in South Africa, high import costs drive up the capital cost. Modular units may be imported, or units may be designed and manufactured locally (where the project owner has a broad knowledge of HK workings). The typical ranges of commonly available turbine units can be seen in Fig. 6 .

To suit the design power output the rotor diameters may be adapted. As an indication of the changes experienced in the power curve for a range of rotor diameters, Fig. 7 was included. The exponential behaviour of the curve is emphasized at larger rotor diameters, allowing significantly higher power output when using larger turbines.

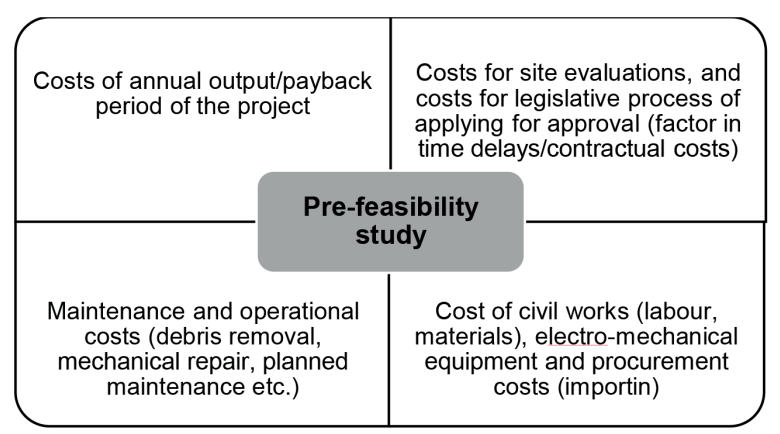

Figure 5. Pre-feasibility study cost considerations

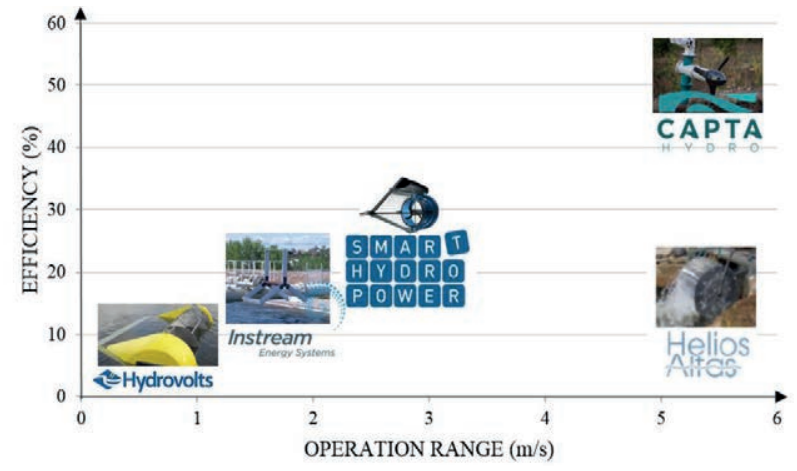

Figure 6. HK turbines (CaptaHydro, 2017) 


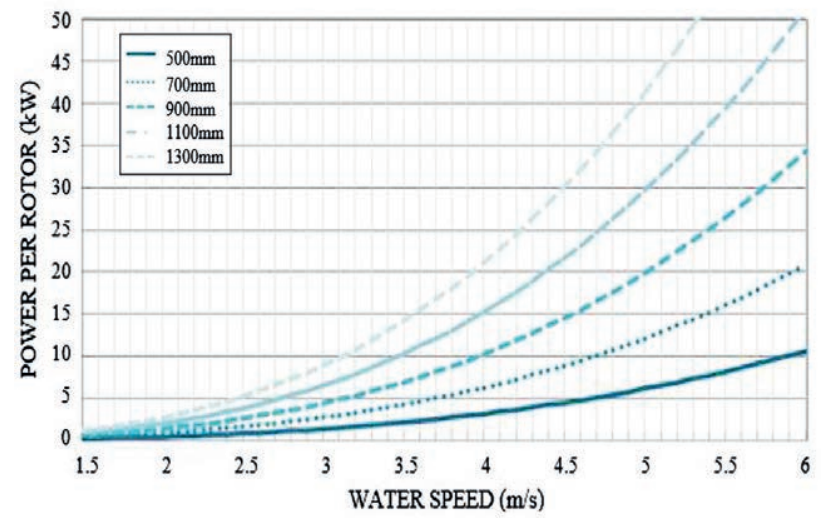

Figure 7. Axial flow rotor diameter comparisons (CaptaHydro, 2017)

\section{Step 3: Grid integration}

The control systems for the HK device are designed according to the specified electricity use, which falls within the selected grid integration method:

- Islanded stand-alone method:

- Control systems including inverters, rectifiers and dump-loads are used to regulate the system

- This will require the development of a mini grid for the distribution of the power produced

- Grid-connected system:

- Stand-alone system requiring a grid connection to synchronise frequency

- Usage of existing transmission lines to feed electricity to the end user (may require additional approvals)

When the grid integration method has been selected the following should be designed or selected as part of the modular turbine unit as supplied by the manufacturer:

- Electric control boards

- Regulation system

- Electric transmission

- Grid connection

\section{Step 4: Legislative assessments and approvals}

In each relevant country certain legislative and regulatory requirements may be applicable when installing a HK system in a canal system. The entities which must be considered in a
South African context are listed in Table 2 (it must be noted that this may change as changes in legislation are introduced and the entities involved may vary as the use of electricity and the size of HK system varies). Although specific to SA, similar entities and aspects may be globally representative. Greater detail on these processes can be seen in (Scharfetter and Van Dijk, 2017).

\section{Step 5: Meeting with stakeholders}

When all stakeholders have been identified, meetings should be arranged with each relevant entity to obtain the required approvals and if required arrange for agreements to be formalised to utilise the water infrastructure asset.

Due to the large changes in process and legislation as the project owner varies (municipality/ private entity) it must be noted the development process described assumes the municipality as project/asset owners for the purpose of this paper (and this process may vary in other cases).

\section{Step 6: Capital procurement}

This phase involves procurement of all equipment required for installation of a complete HK system. This may include (but is not limited to) the following:

- Procurement of materials and equipment required for civil works:

- Procurement of labourers for site work

- Anchor block/foundation material

- Turbine fastening equipment (e.g. anchor cables)

- Bridge structure, hoisting mechanism

- Fencing

- Control room

- Electrical and transmission equipment:

- Turbine control equipment (regulators, inverters, dump-loads)

- Transmission lines / grid connectors / mini grid

- Measuring and monitoring equipment and cabling

- Mechanical equipment:

- Turbine (blades, generator)

- Generator

- Spare parts required for maintenance

\section{Step 7: Project implementation and optimisation}

During project implementation the considerations shown in Fig. 8 are of importance and must be considered, after which the project can be implemented and tested for correct functioning.

Table 2. Small-scale HK assessment and approval guidelines

\begin{tabular}{llc}
\hline Aspect & Entity & Requirement \\
\hline Water/infrastructure use & $\begin{array}{l}\text { Department of Water and Sanitation } \\
\text { (DWS) }\end{array}$ & $\begin{array}{c}\text { [If] DWS is the owner of the infrastructure, the user [may] require written } \\
\text { permission from DWS to use the infrastructure to anchor the HK } \\
\text { turbines for hydropower generation and to provide access to the land }\end{array}$ \\
\cline { 2 - 3 } & $\begin{array}{l}\text { Water user association (WUA) or Water } \\
\text { Board (WB) involved }\end{array}$ & $\begin{array}{c}\text { The project owner may require the statutory body's written } \\
\text { permission to non-consumptively make use of the water in the } \\
\text { infrastructure, to access and modify the infrastructure and receive } \\
\text { acknowledgment and approval for the project }\end{array}$ \\
\hline Environmental & $\begin{array}{c}\text { Provincial Department of Environmental } \\
\text { Affairs (DEA) }\end{array}$ & $\begin{array}{c}\text { Provision of an environmental authorisation should a listed activity } \\
\text { according to the National Environmental Management Act be triggered }\end{array}$ \\
\hline Electricity & National Energy Regulator (NERSA) & $\begin{array}{c}\text { Needs to be informed of the project and depending on the extent of } \\
\text { the electricity generation and distribution infrastructure provided, } \\
\text { issue licences for these activities }\end{array}$ \\
\cline { 2 - 3 } & May be consulted if grid-integration, wheeling or feed-in is considered \\
\cline { 2 - 3 }
\end{tabular}




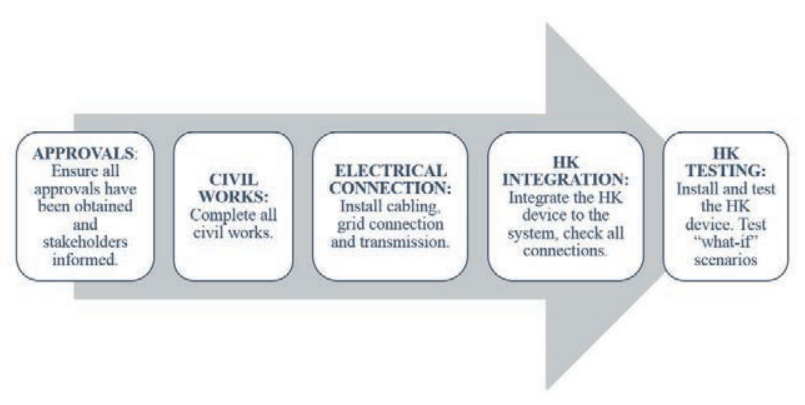

Figure 8. Implementation procedure

During project implementation it may be necessary to optimise the system to obtain a higher output. Some methods of optimisation include:

- Turbine confinement (Shives, 2008)

- Shroud addition (Gaden, 2007)

- Diffuser addition (Gaden, 2007) (Riglin et al., 2014)

- Channel modification (Khan et al., 2008)

- Multiple turbine application (Riglin et al., 2014)

\section{Step 8: Operation and maintenance}

The operation and maintenance of the HK installation will govern the lifespan and functioning of the device. The following aspects are of importance for this procedure:

- Training of operation and maintenance staff

- Maintenance plan and schedule of inspections and cleaning

- Issuing maintenance and operating manuals

During the first year of project implementation, additional problems (such as seasonal debris variations) should be evaluated and the relevant mitigation measures put into place. Correct operation and maintenance of the system will result in an efficient system with a long operational life.

\section{Step 9: Monitoring and evaluation}

For new technologies such as HK systems in South Africa, monitoring and evaluation of the system over its operational life is an important step to understand system functioning within the South African context. This will result in the construction of more reliable, cost-effective systems in the future once a clearer understanding of the roles of all the variables has been attained.

In addition to this, monitoring the systems will allow risk mitigation by allowing quick response times in blockage or potential canal overflow situations, and will also allow reporting when unplanned maintenance may be required due to observed decreases in system outputs. Some important technical aspects which should be monitored include the following:

- Power output and relevant velocity at specific time intervals

- Damming levels (allowing blockage monitoring)

- For future feasibility studies, monitoring and data collection of the following aspects could be valuable:

- Costs incurred over the operational life (maintenance/ operational costs)

- Problems encountered during operational life (blockages/ floods/overtopping/theft)

\section{Boegoeberg case study}

The first HK installation in SA was designed and implemented through benchmarks highlighted in the developed design and implementation process, which are summarized below. The project was initiated by allocated funding for small-scale hydropower development in the !Kheis Local Municipality (LM) in the Northern Cape Province. This LM has a similar problem to numerous other municipalities throughout the country, this being a lack of revenue due to large sections of the community being unemployed and not able to pay for services.

The Boegoeberg irrigation canal runs adjacent to numerous towns and small settlements in the municipality. Small-scale hydropower schemes along this route could allow a sustainable means of supplementing the income of this municipality and reducing its reliance on Eskom.

Selection of a site in the !Kheis Municipality was based on the following criteria:

i. Technical viability:

- Adequate flow velocity

- Demand for electricity

- Adequate cross section (large enough for turbine and turbulence recovery)

ii. System sustainability:

- Anti-theft/ anti-vandalism

- Identified electricity need

- Community support

- System integration effect on canal functioning (water supply should not be compromised by addition of system)

iii. Site resilience:

- Overflow protection of damming effect

- Accessible to municipal workers in case of emergency (e.g. blockage)

iv. Project specifications:

- A representative canal section of what is available in most areas The Groblershoop water treatment works (WTW) site lies in the town of Groblershoop in the !Kheis Municipality. This plant supplies water to the majority of the surrounding areas. The WTW pump station is currently partially supplied by a small solar generation plant erected at the WTW facility. The town of Groblershoop lies approximately $38 \mathrm{~km}$ downstream of the canal offtake (Boegoeberg Dam). The approximate electricity usage of the pumps at the WTW is $25 \mathrm{~kW}$. The selected site lies on the upper region of the Boegoeberg irrigation canal; the layout of the site can be seen in Fig. 9.

The canal has a rectangular shape with a slightly cambered canal bed, the canal drawings were obtained from the Boegoeberg Irrigation Board in original design drawing format. As shown, the selected section is a combination of two straight

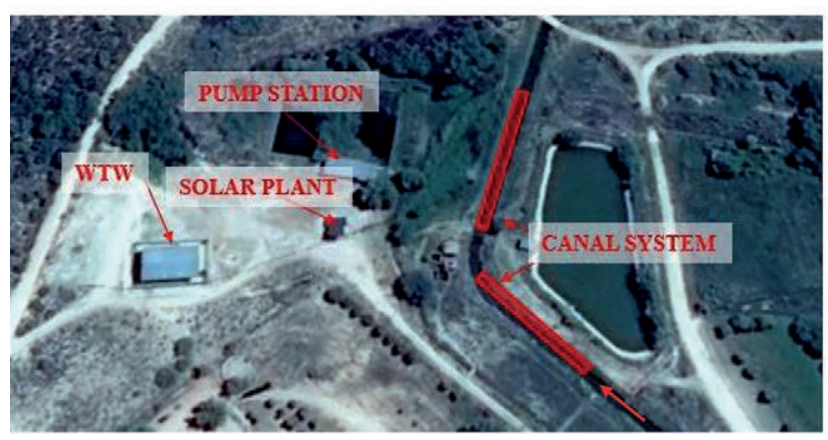

Figure 9. Groblershoop site 
sections; this is ideal for installation as there is less turbulence in these sections. The downstream canal section including the bend as well as the typical section parameters can be seen in Fig. 10. Sections further upstream were not considered as these lie at too great a distance from the control room/demand and would result in long transmission cable lengths (and therefore higher costs and increased possibility of vandalism).

A DWS gauging station (D7H17) which has recorded significant amounts of historical flow data lies approximately $63 \mathrm{~km}$ upstream of the installation section of the canal. The flow recorded over a \pm 10 -year period can be seen in Fig. 11. The trend indicates an annual average of 40 days of zero flow (during maintenance etc.). The average flow during operational periods was found to be $12.5 \mathrm{~m}^{3} / \mathrm{s}$ (Fig. 11). A localised flow (due to other offtakes) of around $6.6 \mathrm{~m}^{3} / \mathrm{s}$ was measured at the selected location for the installation of the HK device through the use of a speedy doppler-type velocity sensor and ultrasonic level sensor. With the flow of $6.6 \mathrm{~m}^{3} / \mathrm{s}$, the flow velocity was expected to be $1.1 \mathrm{~m} / \mathrm{s}$ and measured to be an average of $1.05 \mathrm{~m} / \mathrm{s}$ (measured by a doppler velocity sensor placed on the canal bed).

The turbine selected for the site is shown in Fig. 12 and is specifically designed by Smart Hydropower Gmbh for canal systems. It is placed directly on the flat canal bed and anchored by steel cables to the sides/bottom of the canal. System specifications can be seen in Table 3 . The turbine is equipped with an underwater permanent magnet generator providing AC power to the system. To achieve maximum power output from this specific turbine a flow velocity of $3.1 \mathrm{~m} / \mathrm{s}$ is required. The output curve of the generator is provided in Fig. 13
The Groblershoop WTW already had a facility where power could be generated for one of the pumps by means of solar panels which are also grid connected to supply the remaining pumps (however, this was not functioning due to damaged control equipment). This allowed integration of the HK plant with the existing system (and control equipment).

Table 3. Turbine specifications (SHP, 2017)

\begin{tabular}{llc}
\hline Output $(\mathrm{W})$ & $250-5000$ \\
Dimensions & Length $(\mathrm{mm})$ & 2640 \\
& Width $(\mathrm{mm})$ & 1120 \\
& Height $(\mathrm{mm})$ & 1120 \\
Rotational speed $(\mathrm{r} / \mathrm{min})$ & $90-230$ \\
Weight $(\mathrm{kg})$ & 300 \\
Number of rotor blades & 3 \\
Rotor diameter $(\mathrm{mm})$ & 1000 \\
\hline
\end{tabular}

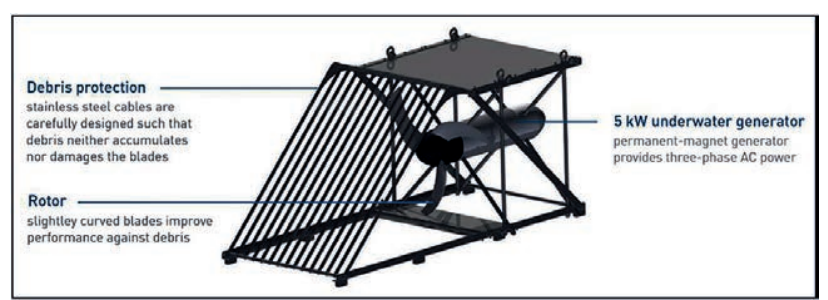

Figure 12. Kinetic turbine for deployment in canal (SHP SMART free stream turbine) (SHP, 2017)

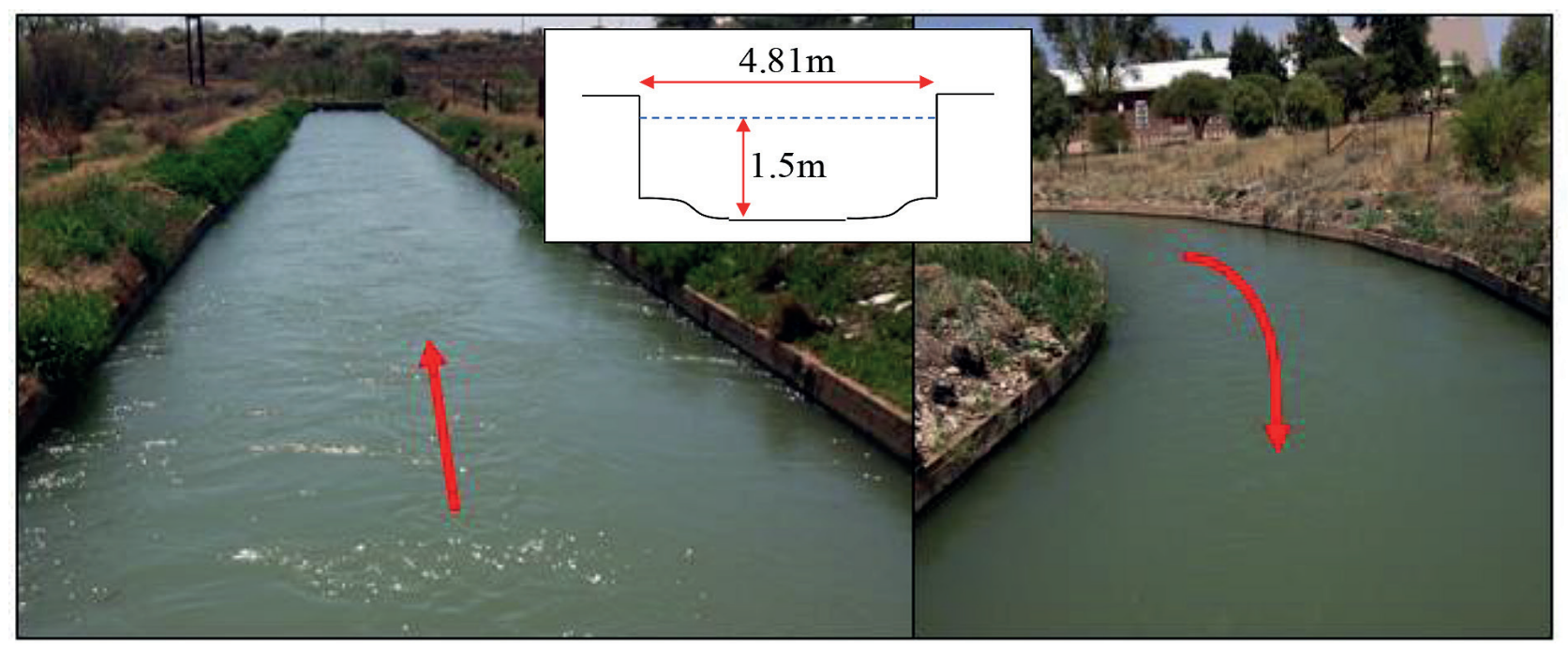

Figure 10. Canal system at the Groblershoop site

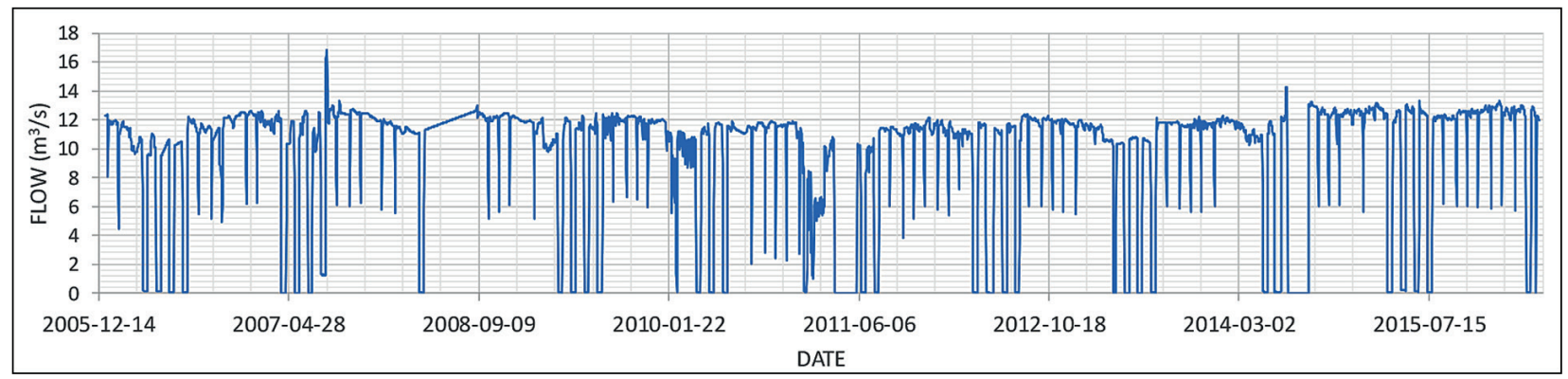

Figure 11. Flowrate in the Boegoeberg Canal Station D7H17 (Dec 2005 to April 2016) 


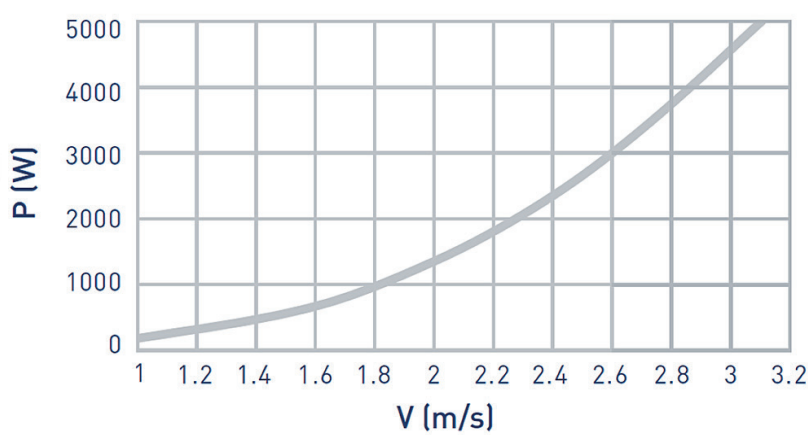

Figure 13. Generator capability (SHP, 2017)

The electronic control system is the intelligence of this renewable energy system (Fig. 14). Integrated inside the electrical cabinet is a reverse control (to remove accumulated debris from the blades), optional auxiliary devices, customizable battery storage interface (it has a built-in battery charger) and integrated monitoring system (monitoring control board). The basic layout of the installation is depicted in Fig. 15.

For hydropower projects developed at local level, the institutional powers, functions, roles and responsibilities of municipalities are of utmost importance. In the context of the four major regulatory requirements necessary to initiate and implement small-scale hydropower projects, namely a Water Use Licence (in terms of the National Water Act (NWA) (RSA, 1998a)), an Environmental Authorisation (in terms of the National Environmental Management Act (NEMA) (RSA, 1998b)), an Electricity Generation Licence and an Electricity Distribution Licence (in terms of the Electricity Regulation Act (ERA) (RSA, 2006)), the DWS (or the regional departmental offices or the catchment management agency, where these are established and have the authority), the provincial office of the Department of Environmental Affairs (DEA) and National Energy Regulator of South Africa (NERSA), would be the primary stakeholders involved in this type of hydropower project, over and above the project initiator.

In the context of local electrification through small-scale hydropower technologies, the DWS is a primary stakeholder. The DWS has the mandate to protect and manage SA's water resources. Furthermore, the DWS owns waterworks across SA such as weirs, irrigation canals and dams which could be utilised to generate electricity (in this case the Boegoeberg irrigation canal). For this study, the project-specific institutional stakeholders are identified in Table 4. The roles of each stakeholder during the project are shown under project specification. The project formed part of the 'Draft policy on sustainable hydropower generation' which allowed a simpler process of approval.

The infrastructure components required for the installation of the HK turbines are listed in three sections, namely, civil components, electro-mechanical components and electrical components:

i. Electro-mechanical components

- SHP free stream turbine (Equipped with $5 \mathrm{~kW}$ underwater generator and rotor)

ii. Civil components

- Concrete block foundation for cable hoist

- Turbine lifting system

iii. Electrical components

- Turbine control equipment

- Flow meter

- Level sensors

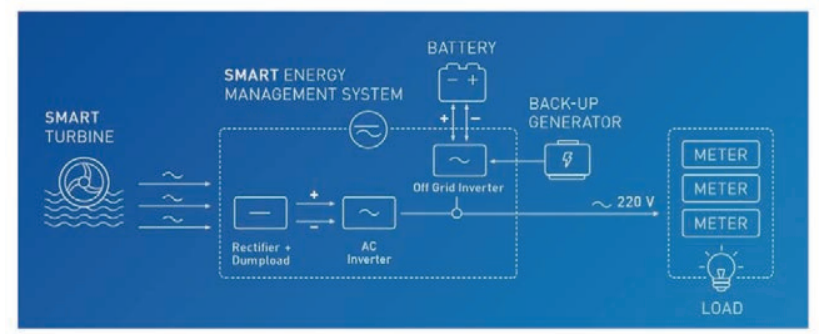

Figure 15. System layout (SHP, 2017)

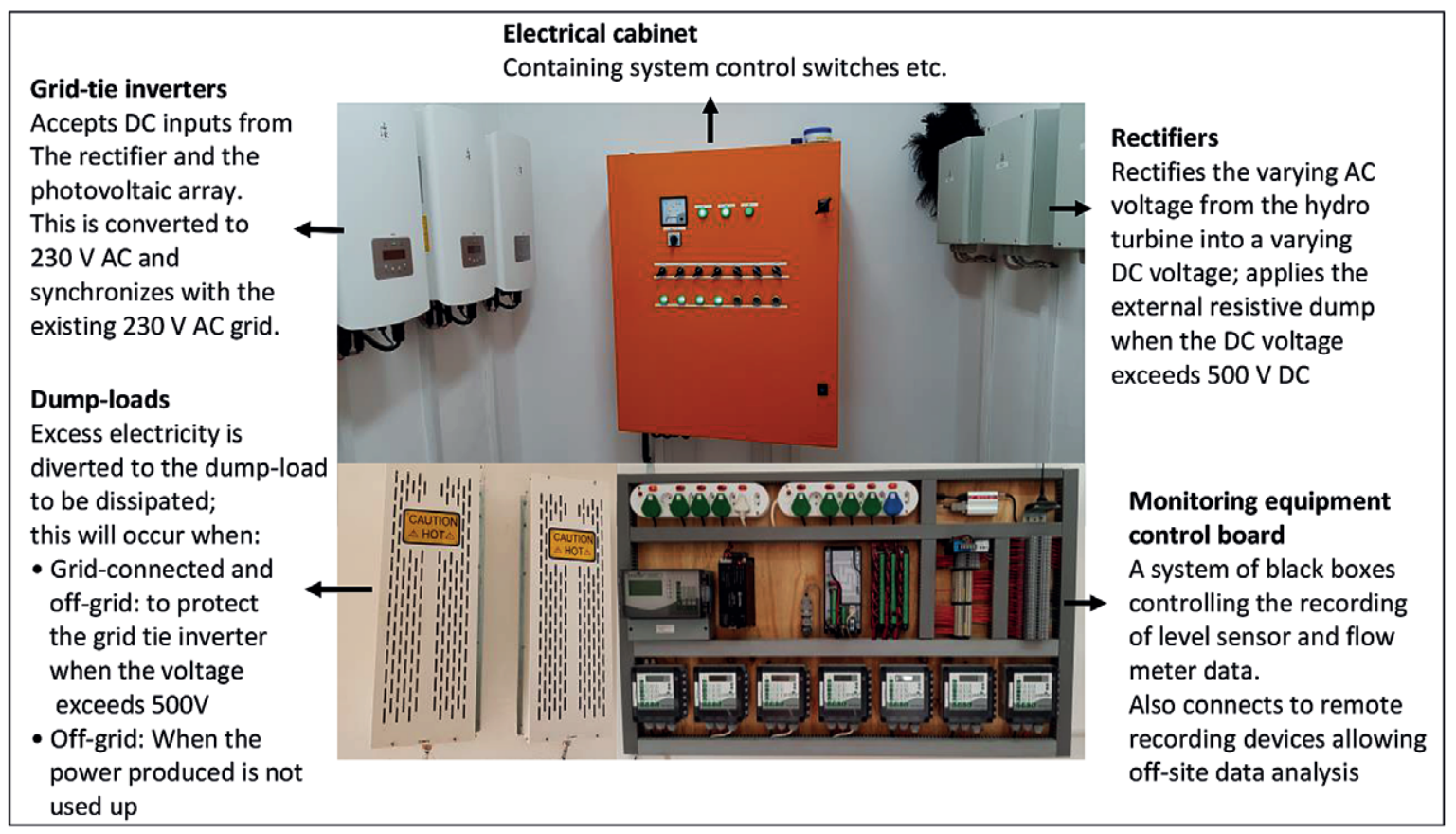

Figure 14. Electrical management system components (Control room) 
Table 4. Project-specific institutional stakeholders Groblershoop Water Treatment Works

\begin{tabular}{|c|c|c|c|}
\hline No. & Stakeholder & Role and responsibility & Project specification \\
\hline 1 & $\begin{array}{l}\text { Department of Science and } \\
\text { Technology (DST) }\end{array}$ & Funder & Funds obtained for the project duration \\
\hline 2 & WRC & Implementing Agent for the DST & Reports submitted \\
\hline 3 & DWS & $\begin{array}{l}\text { Owner of irrigation canal } \\
\text { Owner of land on which the irrigation canal is } \\
\text { located } \\
\text { Custodian of the water resource }\end{array}$ & $\begin{array}{l}\text { A series of meetings set-up to obtain approval } \\
\text { Signee on the memorandum of agreement (MoA) } \\
\text { between all entities involved to ascertain approval }\end{array}$ \\
\hline 4 & !Kheis LM & $\begin{array}{l}\text { Hydropower project owner (asset will be listed } \\
\text { onto the LM's Asset Register) } \\
\text { All regulatory submissions would be in the name } \\
\text { of the !Kheis LM and for the !Kheis LM } \\
\text { Operation \& maintenance of hydropower } \\
\text { generation plants and the electricity } \\
\text { transmission infrastructure }\end{array}$ & $\begin{array}{l}\text { A series of meetings were set-up to obtain } \\
\text { approval and knowledge of municipal roles and } \\
\text { responsibilities concerning the installation } \\
\text { Co-signee of MoA }\end{array}$ \\
\hline 5 & Citizens of the !Kheis LM & $\begin{array}{l}\text { Beneficiaries of the project's service delivery } \\
\text { outcomes }\end{array}$ & $\begin{array}{l}\text { Local labourers were hired and trained to perform } \\
\text { maintenance on such an installation } \\
\text { Continuous employment to operate and maintain }\end{array}$ \\
\hline 6 & Boegoeberg WUA & Operator of Boegoeberg canal & $\begin{array}{l}\text { Meetings were set-up to inform WUA of all } \\
\text { construction plans and obtain approval } \\
\text { Notified and requested approval during any } \\
\text { modification/alteration to canal } \\
\text { Co-signee of MoR }\end{array}$ \\
\hline 7 & NERSA & Electricity regulator & $\begin{array}{l}\text { No licence required as the electricity produced is } \\
\text { for 'own-use' and small scale of generation }\end{array}$ \\
\hline 8 & Eskom & Electricity distributor & $\begin{array}{l}\text { No approval/licensing required, no Eskom owned } \\
\text { distribution lines used }\end{array}$ \\
\hline 9 & $\begin{array}{l}\text { Northern Cape Provincial } \\
\text { DEA }\end{array}$ & $\begin{array}{l}\text { Provision of an environmental authorisation } \\
\text { should a listed activity according to the NEMA be } \\
\text { triggered }\end{array}$ & $\begin{array}{l}\text { No triggers for this authorisation, therefore not } \\
\text { required }\end{array}$ \\
\hline 10 & University of Pretoria & Planning and design engineers & Responsible for project implementation \\
\hline
\end{tabular}

All equipment required for installation was procured together with the completion of civil works (listed above) to allow turbine installation. The velocity in the canal was measured as around $1.2 \mathrm{~m} / \mathrm{s}$ at the point of installation which provided a lower range of application on the power curve (Fig. 13). This also proved true at the initial testing phase where a maximum output of $228 \mathrm{~W}$ was achieved (placing the turbine into the flow area as specified by manufacturer). Due to this optimisation of the section was considered. To achieve a higher velocity through the turbine the option of canal narrowing at the installation points thus creating a venturi effect and speeding up the flow entering the turbine was considered. This was done through the use of steel plates anchored onto a hinge point on the canal wall.

To allow installation of a HK system in SA more information is required on the impacts such devices could have on the canal functioning and water security as a whole. A numerical model using HEC-RAS was developed for both scenarios with and without the narrowing. The findings of such numerical simulations were compared with the constructed test installation from which data could be collected and analysed.

To allow an indication of 'worst case' infrastructural influences, the numerical modelling was used in the testing process identified in 2 phases. Phase 1 included the 'worst case' of full turbine grid blockage which was modelled by an inline structure. The length of the blockage was chosen as $3 \mathrm{~m}$ which is the length of the turbine plus an additional $0.75 \mathrm{~m}$ allowing for possible debris build up (trees, shrubs etc.)

The maximum damming level was found to be $40 \mathrm{~mm}$ just upstream of the turbine, which then returns to normal flow depth approximately $2.7 \mathrm{~km}$ upstream of the installation point. This large backwater effect resulted from the relatively flat canal bed and subcritical flow pattern. The highest damming levels lie within the available freeboard and therefore no overtopping was expected. The damming levels comparing to the 'no turbine' scenario can be seen in Fig. 16.

Phase 2 including narrowing the canal by a total of $1.2 \mathrm{~m}$ per side. To model the narrowed width new cross-sections were added to the HEC-RAS model to simulate the new incrementally narrowed section. The blocked turbine was added to the narrowed section, similarly to Phase 1 .

Both scenarios at the narrowing of the canal, first, with no installed turbine and, second, with a fully blocked turbine, can be seen in Fig. 17. The maximum damming level of the Phase 2 canal narrowing with a fully blocked turbine grid was found to be around $290 \mathrm{~mm}$ just upstream of the blockage and the recovery distance of damming levels was $6.3 \mathrm{~km}$ upstream. For the scenario of narrowing alone without the turbine the damming was found to be around $70 \mathrm{~mm}$ with a recovery distance of $4.2 \mathrm{~km}$ upstream.

During the blocked turbine Phase 2 modelled scenario with the narrowed width, the canal showed overtopping at distances of 440-1 $800 \mathrm{~m}$, which lies about 360-1 $700 \mathrm{~m}$ upstream of the blockage. Consideration was given to heightening of this section when permanent narrowing was considered; however, due to the original canal drawings being used to create the model, and alterations (in terms of heightening the canal wall) having been made since initial construction, it allowed the flexibility for the damming required for the narrowing (without alterations). 


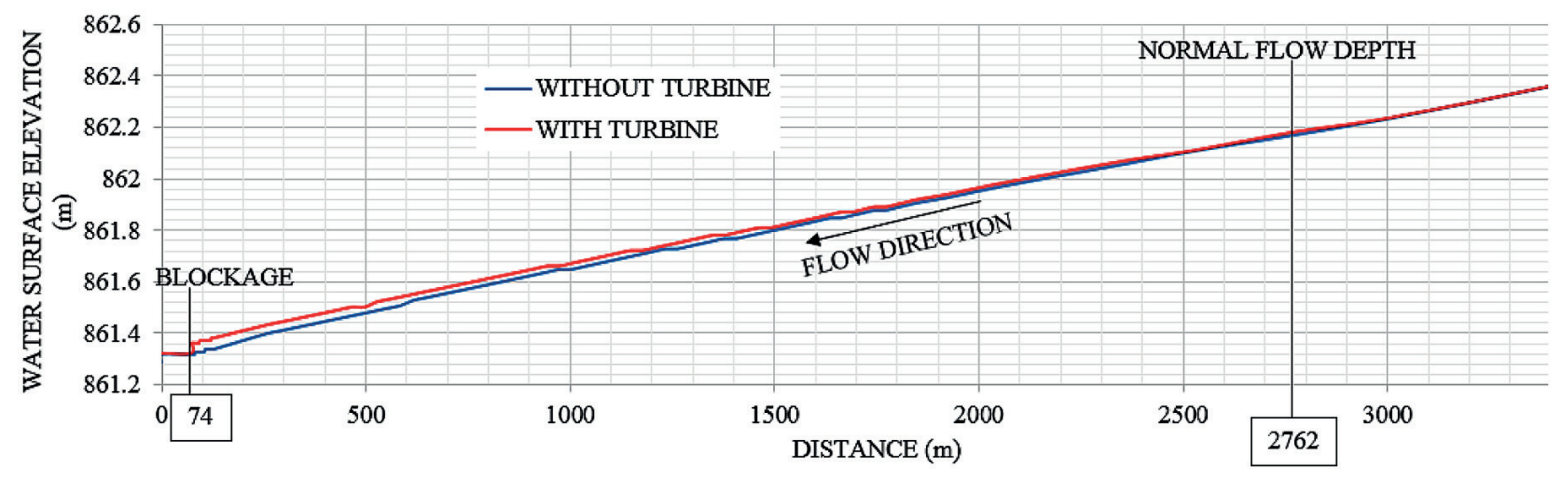

Figure 16. Phase 1 blockage damming levels

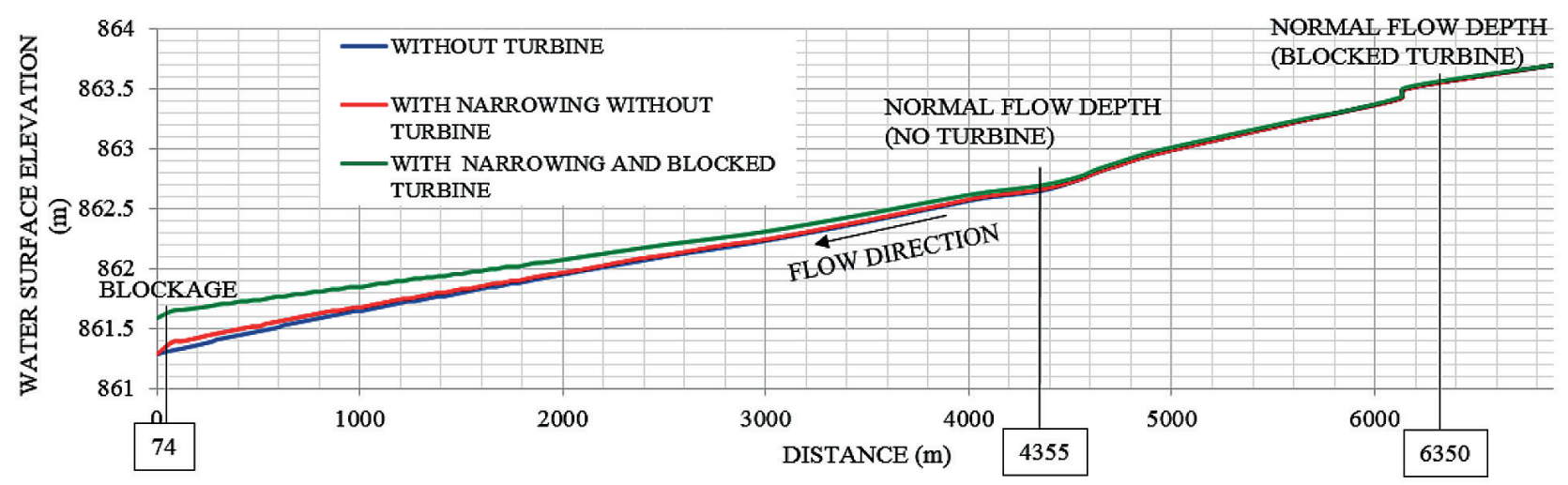

Figure 17. Phase 2 blockage damming levels

The physical testing phase included the construction indicated in Fig. 18. Phase 1 included a single turbine which was temporarily anchored from $8 \mathrm{~mm}$ diameter steel cables (lifting capacity of $750 \mathrm{~kg}$ ) attached to concrete block foundations.

The damming effects of the canal narrowing due to the installation of the HK turbine were measured by means of level sensors at the installation point and a distance upstream (allowing measurement of the upstream effects). The flow velocity was measured at various points by use of a hand-held velocity propeller sensor (wading rod) to allow understanding of the flow characteristics. The results proved a $70 \%$ increase in velocity from the canal narrowing with a maximum damming effect of $100 \mathrm{~mm}$ (found to be $70 \mathrm{~mm}$ with numerical modelling); additional details are shown in Table 5.

For Phase 2 testing the turbine was placed in the flow (within the narrowed flume section) and the water levels, flow velocity and the impact on water levels further upstream were once again recorded. The freeboard available proved to be sufficient for the damming effects (Table 5). The effects on the canal system were compared to numerical model results and the model was calibrated accordingly. This allowed re-modelling in the numerical model and thus assisted with the design of the final system with greater accuracy.

The final conclusions reached from the correlated physical and numerical testing results can be seen in Table 5 .

From the results of the temporary test installation a permanent design was completed. A total of 4 turbines were installed in series along two narrowed sections $45 \mathrm{~m}$ apart ( 2 turbines in each section) with both sections being narrowed to a width of $2.41 \mathrm{~m}$. The final design results in an increased output of $3.9 \mathrm{~kW}$ (increased velocity of $2.8 \mathrm{~m} / \mathrm{s}$ ) per turbine and thus a total system production of around $15.6 \mathrm{~kW} 89 \%$ of

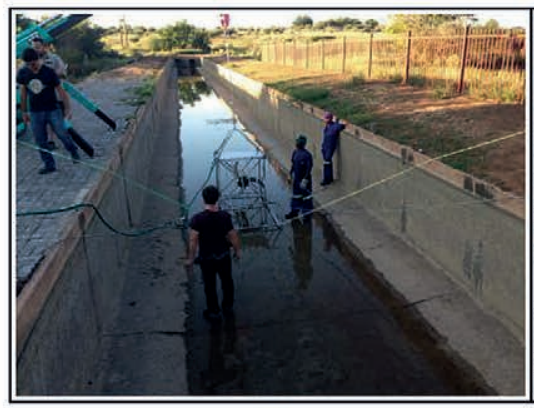

(a)

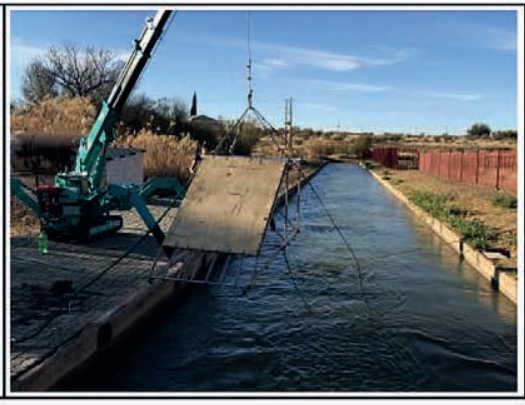

(b)

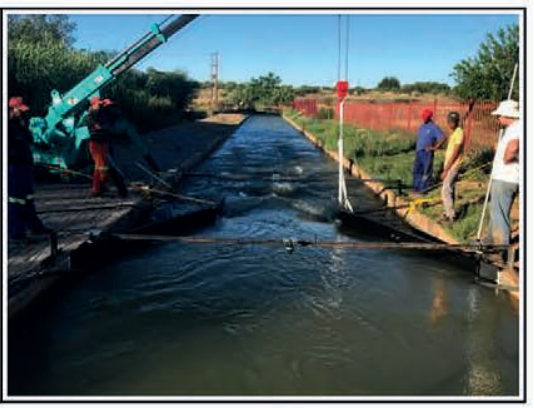

(c)

Figure 18. Testing (a) turbine placement testing (b) blocked turbine testing (c) Narrowed section testing 
Table 5. Testing results summary

\begin{tabular}{|c|c|c|c|}
\hline Scenario & & Maximum damming effects & Conclusions reached \\
\hline \multirow[t]{2}{*}{$\begin{array}{l}\text { Phase 1: } \\
\text { Cable anchored } \\
\text { turbine }\end{array}$} & $\begin{array}{l}\text { Normal operating } \\
\text { turbine }\end{array}$ & $\begin{array}{l}30 \mathrm{~mm} \text { maximum damming } \\
\text { recorded at the point of } \\
\text { installation and } 50 \mathrm{~m} \text { further } \\
\text { upstream }\end{array}$ & $\begin{array}{l}\text { The turbine proved to have minimal effects on the canal; } \\
\text { with no visual or noise disturbances and minimal } \\
\text { damming }\end{array}$ \\
\hline & $\begin{array}{l}\text { Blocked turbine } \\
\text { (Fig. 18b) }\end{array}$ & $\begin{array}{l}60 \mathrm{~mm} \text { maximum damming at the } \\
\text { point of installation, reducing to } \\
50 \mathrm{~mm} \text { within } 50 \mathrm{~m} \text { upstream }\end{array}$ & $\begin{array}{l}\text { If the turbine grid is fully blocked by debris, etc., no } \\
\text { interruption of the water supply of the Boegoeberg } \\
\text { canal will be experienced (no overtopping etc.) }\end{array}$ \\
\hline \multirow[t]{2}{*}{$\begin{array}{l}\text { Phase 2: } \\
\text { Canal narrowing } \\
\text { with cable } \\
\text { anchored turbine }\end{array}$} & $\begin{array}{l}\text { Normal operating } \\
\text { turbine }\end{array}$ & $\begin{array}{l}100 \mathrm{~mm} \text { maximum damming at the } \\
\text { point of installation, reducing to } \\
90 \mathrm{~mm} \text { within } 50 \mathrm{~m} \text { upstream }\end{array}$ & $\begin{array}{l}\text { By narrowing the canal section to obtain optimal output } \\
\text { the damming effect remains within the available } \\
\text { freeboard; therefore, the final installation should } \\
\text { function well with minimal disturbance on the system }\end{array}$ \\
\hline & Blocked turbine & $\begin{array}{l}140 \mathrm{~mm} \text { maximum damming at the } \\
\text { point of installation, reducing to } \\
100 \mathrm{~mm} \text { within } 50 \mathrm{~m} \text { upstream }\end{array}$ & $\begin{array}{l}\text { If the turbine grid is fully blocked by debris, etc., no } \\
\text { significant interruption of the water supply of the } \\
\text { Boegoeberg canal will be felt (no overtopping etc.); } \\
\text { improvements can be made to allow flow over narrow- } \\
\text { ing plates or raising of the channel walls in this area }\end{array}$ \\
\hline
\end{tabular}

the year (accounting for maintenance and canal dry times). This design can be seen in Fig. 19 and is currently under construction. The design of the system allows simplified removal of each turbine if necessary (in case of blockages) and operational flexibility; the entire system is removable and can be altered and adjusted if necessary.

During the design life of a HK device, efficient functioning is crucial to obtaining design outputs. The energy production is predicted and considered during the preliminary design analysis; this is directly related to the production and therefore profitability/success of the installation. During the operational phase testing, routine maintenance was required due to debris build up (as indicated in Fig. 20). The maintenance strategy that was found to be effective for correct functioning of the installation through its design life involved a single operator hired with the following duties:

- Weekly visual checks and clearing of visible blockages

- Turbine removal and cleaning at 2-week intervals

- Turbine inspection and clearing at all canal shutdown periods, and first day of full flow (as build up occurs during start-up)

- Impromptu response to alarm system linked to level sensors indicating sudden increases in water level and thus unplanned clearing/removal and cleaning as required. During the HK test installation various risks were identified which could impact future developments and result in delays or additional costs:

- Potential of theft and vandalism of the installation during construction, which could result in additional expenditure for fencing and additional security measures

- The test installation site is in close proximity to a school in the town of Groblershoop. In summer temperatures rise above $40^{\circ} \mathrm{C}$ and children tend to swim in the canal systems (although forbidden); measures had to be taken to prevent

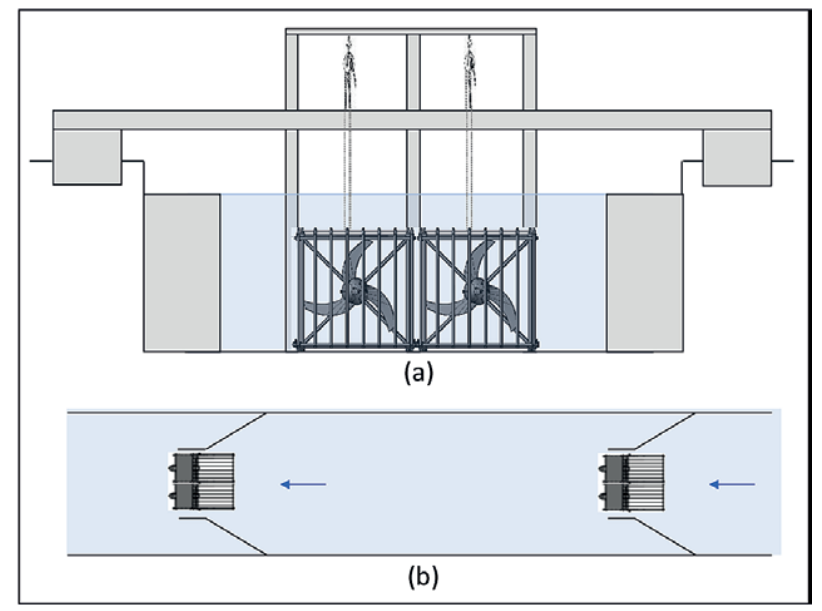

Figure 19. (a) Front view of final design (b) top view of final design with turbines $45 \mathrm{~m}$ apart

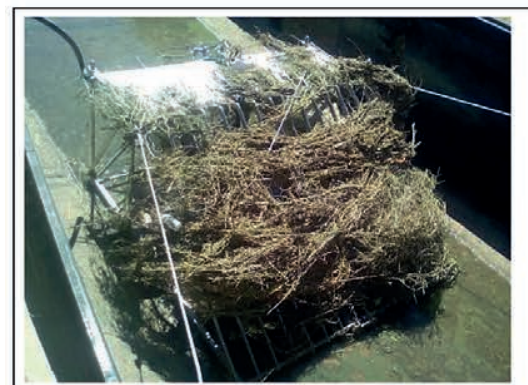

(a)

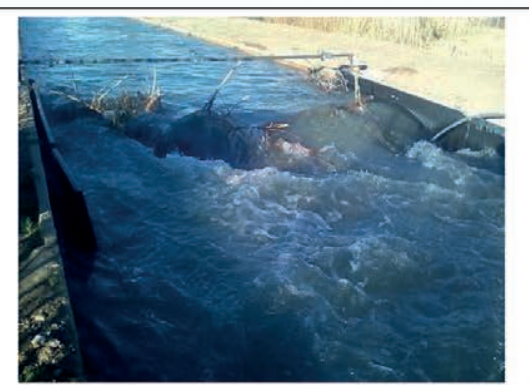

(b)

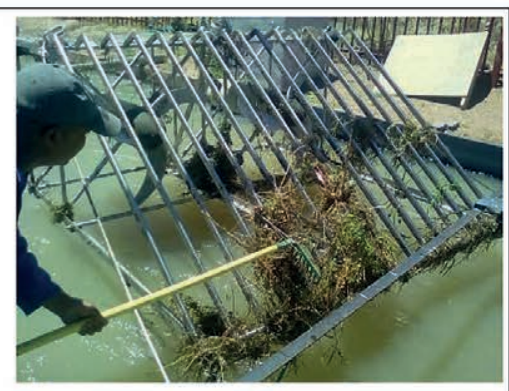

(c)

Figure 20. Debris blockage (a) during maintenance period (b) major debris build up after a 2-week interval (c) turbine removal and cleaning at 2-week interval 
swimming in the section (to prevent injury or fatalities from spinning blades) and additional protective casing on the turbine (resulting in additional costs)

- Larger than expected debris, such as deceased livestock floating down the canal, due to livestock and wildlife drinking from the canal (as no barrier exists around the canal) and occasionally falling in. This could potentially result in turbine blockages; therefore, a warning system must be included in the installation to allow for quick removal in such cases.

- The legislation in South Africa is not yet in place to allow entities (municipalities or developers) to utilise DWS infrastructure for hydropower development in any form. This test installation requires special permission and a memorandum of agreement $(\mathrm{MoA})$ between the !Kheis Local Municipality, the Boegoeberg Water User Association (WUA) and the DWS and is a test case for new legislation.

- Due to a lack of specific policy instated in South Africa, which would allow a streamlined process of installation, delays in the process may occur.

- The low velocities in most canal sections result in low efficiency systems due to the exponential behaviour of the power curve; however, as narrower sections or confined sections with a greater flow velocity are selected for installation, additional problems such as complete blockage (due to the turbine covering the majority of the smaller cross section) and large damming effects may occur. Due to this the risk of overflow and thus water loss to the WUA increases and thus the viability of the project decreases (civil works costs increase); it can also result in reluctance of the WUA to agree to the installation.

- Maintenance of the HK system remains a problem in South Africa; municipalities do not have the money and thus not the workforce to complete maintenance of the systems. The debris during short testing periods was evident which could result in large debris build-up over time and with no maintenance this could result in an inefficient system which is prone to blockage stoppages.

\section{SUMMARY AND CONCLUSIONS}

South Africa, the country with the second largest installed hydropower capacity in Africa, produces less than $5 \%$ of its total electricity demand from hydropower. However, multiple studies have indicated the unexploited potential available (Kusakana and Vermaak, 2013) (Loots et al., 2015). This highlights the lack of and need for innovative hydropower research and installations in Africa. In South Africa, mainly due to a relative scarcity of surface water, there is a prevailing perception that the potential for hydropower development is rather low. The largest percentage $(>60 \%)$ of water is made available for the agricultural sector, delivered through an extensive water supply network consisting of weirs/intake structures, pipelines, tunnels, siphons, canals, chutes, etc.

Although there is significant $\mathrm{HK}$ potential, globally there is little technical literature or validation of successful installations of HK systems. The objective of this study was to address this problem and develop a HK design and implementation process to provide a guideline to $\mathrm{HK}$ installations. Literature on smallscale hydropower and specifically HK systems both locally and internationally were reviewed. Although no HK installation had been constructed in South Africa, the potential of these systems in rivers has previously been investigated at a very high level when considering several technologies (Koko and Kusakana,
2014) and a DWS asset management study illustrated the vast network of canals allowing further HK potential in the country.

A pilot project of a $\mathrm{HK}$ installation to showcase the installation possibilities was constructed. The working of the device was tested and as a result of the methodology followed during the study the following conclusions have been drawn. These conclusions should be read in the context of the study:

- The modular HK system was installed with all required aspects to operate the system on a permanent basis. This allowed a showcase of the technology in the South African context.

- With the required maintenance met (from debris/ blockages) and the correct site selection, HK technology could be used as an additional sustainable renewable energy source in South Africa.

- As the majority of canal systems pose a controlled environment with a constant uniform supply of water (except during short shut-off intervals), with careful site selection and feasibility studies, HK energy systems in canal networks in South Africa can be a feasible alternative energy source. With pilot installations such as these, the way to a streamlined, simplified regulatory and legislative process for the installation of HK systems in South Africa is demonstrated.

- The design, implementation and testing of a HK turbine within the South African environmental context highlighted all important aspects of the design and procedures necessary, thus assisting future installations.

- When designing new canal systems, the potential opportunity to include HK systems should be considered and some design requirements already provided, e.g., designing parts of the canal for faster velocities and higher canal walls in anticipation of damming.

Through the testing and investigation of this modern form of hydropower, a design and implementation process for the integration of $\mathrm{HK}$ turbines was formulated, which allows for an improved and streamlined implementation process where uncertainties are reduced.

\section{ACKNOWLEDGEMENTS}

This research was made possible by the financial support of the South Africa Department of Science and Technology, Water Research Commission and University of Pretoria whose support is acknowledged with gratitude. Additionally, the project was completed with support from the Boegoeberg Water User Association as a pilot project under the DWS General notice: Draft Policy on Sustainable Hydropower Generation.

\section{REFERENCES}

CAPTAHYDRO (2017) Capta SC: For fast flowing canals. URL: http:// www.captahydro.com/capta-sc.html (Accessed 9 August 2017).

DME (Department of Minerals and Energy, South Africa) (2003) White Paper on Renewable Energy. Department of Minerals and Energy, Pretoria.

DWS (Department of Water and Sanitation, South Africa) (2015) Strategic overview of the water services sector in South Africa. Version 4. Department of Water and Sanitation, Pretoria.

DWS (Department of Water and Sanitation, South Africa) (2016a) Condition Assessment Audit of irrigation scheme infrastructure: Cluster: Central, Scheme: Sand-Vet GWS. Scheme Report. Department of Water and Sanitation, Pretoria.

DWS (Department of Water and Sanitation, South Africa) (2016b) Condition Assessment Audit of irrigation scheme infrastructure: Cluster: Central, Scheme: Orange Riet GWS. Scheme Report. Department of Water and Sanitation. Pretoria. 
DWS (Department of Water and Sanitation, South Africa) (2016c) Condition Assessment Audit of irrigation scheme infrastructure: Cluster: Central, Scheme: Hartbeespoort GWS. Scheme Report. Volume 1 (2.4). Department of Water and Sanitation, Pretoria.

GADEN DLF (2007) An investigation of river kinetic turbines: Performance enhancements, turbine modelling techniques and an assessment of turbulence models. MSc thesis, University of Manitoba.

GADEN DLF and BIBEAU EL (2006) Increasing power density of kinetic turbines for cost-effective distributed power generation. University of Manitoba, Manitoba.

GUNAWAN B, NEARY VS, MORTENSEN J and ROBERTS JD (2017) Assessing and testing hydrokinetic turbine performance and effects on open channel hydrodynamics: an irrigation canal case study. U.S Department of Energy, Albuquerque. https://doi. org/10.2172/1367421

HYDRO4AFRICA (2017) hydro4africa.net. URL: http://hydro4africa. net/HP_database/country.php?country=South\%20Africa (Accessed 05 April 2017).

IFC (2013) Toward universal energy access: designing a new household electrification strategy for South Africa. International Finance Corporation, South Africa.

KHAN MJ, BHUYAN G, IQBAL J and QUAICOE JE (2008) Hydrokinetic energy conversion systems and assessment of horizontal and vertical axis turbines for river and tidal applications: A technology status review. Appl. Energ. 861823 1835. https://doi.org/10.1016/j.apenergy.2009.02.017

KOKO PS and KUSAKANA K (2014) Techno-economic analysis of an off-grid micro-hydrokinetic river system as a remote rural electrification option. Central University of Technology, Free State, South Africa.

KUSAKANA K and VERMAAK HJ (2013) Hydrokinetic power generation for rural electricity supply: Case of South Africa. Renewable Energ. 55 467-473. https://doi.org/10.1016/j. renene.2012.12.051

LOOTS L, VAN DIJK M, BARTA B, VAN VUUREN SJ and
BHAGWAN JN (2015) A review of low head hydropower technologies and applications in a South African context. Renewable Sustainable Energ. Rev. 50 1254-1268. https://doi. org/10.1016/j.rser.2015.05.064

MEAAI (2011) Energy Report 2011. Ministry of Economic Affairs, Agriculture and Innovation, The Netherlands.

RSA (Republic of South Africa) (1998a) National Water Act. Act No. 36 of 1998. Government Gazette 19182. Government Printer, Cape Town

RSA (Republic of South Africa) (1998b) National Environmental Management Act. Act No. 107 of 1998. Government Gazette 19519. Government Printer, Cape Town.

RSA (Republic of South Africa) (2006) Electricity Regulation Act. Act No. 4 of 2006. Government Gazette 28992. Government Printer, Cape Town.

RIGLIN J, SCHLEICHER W and OZTEKIN A (2014) Diffuser optimisation for a micro-hydrokinetic turbine. ASME International Mechanical Engineering Congress and Exposition, Montreal, Canada. https://doi.org/10.1115/imece2014-37304

SCHARFETTER B and VAN DIJK M (2017) Legislation governing the implementation of small-scale hydropower projects for rural electrification in South Africa. J. Energ. South. Afr. 28 (2) 14-28. https://doi.org/10.17159/2413-3051/2017/v28i2a2005

SHIVES MR (2008) Hydrodynamic modelling, optimisation and performance assessment for ducted and non-ducted tidal turbines. Masters dissertation, Carleton University, Ottawa.

SHP (2017) Smart Hydro Power. URL: https://www.smart-hydro.de/ renewable-energy-systems/hydrokinetic-turbines-river-canal/ (Accessed 15 January 2017).

VAN VUUREN SJ, BLERSCH CL and VAN DIJK M (2011) Modelling the feasibility of retrofitting hydropower to existing South African dams. Water SA 37 (5) 679-692. https://doi.org/10.4314/wsa.v37i5.5

WHITE J (2011) Viability of Small-Scale Hydropower in South Africa. University of Cape Town. Cape town, South Africa. https://doi. org/10.15641/ghi.v2i1.728 